\title{
Homens judeus e relações de gênero na cidade de São Paulo ${ }^{1}$
}

\author{
Ethel V. Kosminsky*
}

\section{Judeus na cidade de São Paulo}

Os dados do censo de 1940 mostram que mais de $80 \%$ da população judaica no Brasil se concentrava no estado de São Paulo, na cidade do Rio de Janeiro (antigo Distrito Federal) e no estado do Rio Grande do Sul, respectivamente em número de 20.379 pessoas; 19.473 pessoas; e 6.619 pessoas. Na cidade de São Paulo, a maior parte - procedente da Europa Oriental - se concentrava no bairro do Bom Retiro (Lesser, 1995: 317). Os dados do Censo Nacional de 1991 indicam um total de 86.417 judeus no Brasil, dos quais 38.843 estabelecidos no município de São Paulo (Decol, 2000).

A partir do final da década de 1940, os imigrantes judeus (lojistas e fabricantes), que haviam ascendido socialmente, perceberam as desvantagens de residir em um bairro misto, industrial-comercial e ao mesmo tempo residencial, muito embora, naquele tempo, o "alto" do Bom Retiro já fosse nitidamente de classe média (Febrot, 1990:221). Muitos mudaram-se então para o bairro de Higienópolis e para os Jardins (Kosminsky, 2002).

Para aqueles que não haviam ascendido socialmente, o Bom Retiro havia se tornado demasiado caro. Para muitos a Vila Mariana, um bairro de classe média pobre, na época, surgiu como uma alternativa.

Nem todos os judeus, porém, mudaram-se do Bom Retiro. Segundo os dados do censo de 1980, o Bom Retiro apresentava a porcentagem mais elevada de concentração de judeus: $21,4 \%$ do total da população do bairro. Em seguida, o bairro de Santa Cecília, no qual os judeus representavam pouco mais de $8 \%$ da população local. Em nenhum destes bairros, no entanto, os judeus constituíam a maioria da população. Infelizmente, não dispomos de dados recentes, que mostrem a proporção atual de judeus residentes no bairro do Bom Retiro e nem nos demais bairros. É importante assinalar que, com o fim das migrações, São Paulo também registrou uma perda significativa do número de judeus a partir de 1980 . Os que se identificaram como judeus diminuíram de 41.000 em 1980 para menos de 39.000 em 1991 (Decol, 2000:18).

\footnotetext{
* Professora Livre-Docente de Sociologia do curso de Ciências Sociais da Universidade Estadual Paulista-UNESP - Campus de Marília (Aposentada). Professora adjunta de Sociologia do Queens College/CUNY (2008-2013).
} 
A inserção dos judeus sefarditas de língua ladina foi diferente daquela dos judeus da Europa Oriental, conforme apontou Boris Fausto. "Nos dois casos, a atividade inicial como mascate parece ter sido relevante como fonte de 'acumulação primitiva' de recursos. A partir daí, os caminhos se separaram, pois os askenazim dedicaram-se sobretudo ao comércio de móveis e de tecidos e à indústria", enquanto que os sefarditas entraram para "o comércio prestigioso de café, algodão e cereais", na época, década de 1920, o café era o principal produto brasileiro de exportação.

Essa separação tem muito a ver com a época em que cada um dos grupos chegou ao Brasil. Quando os askenazim reuniram condições para tentar um empreendimento de maior vulto, as brechas de entrada no setor cafeeiro haviam se reduzido bastante. Além disso, a crise de 1929 afastouos dessa atividade. Guiados por seu faro nos negócios e pelas condições existentes, eles acertaram na escolha, integrando-se ao avanço do comércio e da indústria ocorrido no Brasil, sobretudo após 1930 (Fausto, 1997: 38).

Os imigrantes judeus-orientais ou sefarditas de língua árabe fixaram-se "na Moóca, Brás e depois no Ipiranga; a maioria dos sefaradis buscou regiões no centro comercial de São Paulo e Bela Vista. Poucos anos depois, dispersaram-se pela Consolação e Jardins" (Mizrahi, 2003: 83). A maioria dos judeus da Moóca dedicou-se ao comércio ambulante como prestamista, comprando mercadorias

na rua Oriente ou na 25 de Março, no Brás, onde cristãosmaronitas e muçulmanos predominavam no comércio atacadista de diversos gêneros3. Poucos procuravam mercadorias com os asquenazis do Bom Retiro; os que trouxeram capital aplicaram-no em pequenos estabelecimentos. (...) Ambulantes judeus conseguiram em pouco tempo abrir pequenos estabelecimentos nas ruas do Brás, Oriente e 25 de Março, vendendo armarinhos, tecidos e artigos religiosos católicos. $O$ sucesso dos 'síriolibaneses' no setor textil estimulava empreendimentos de comerciantes judeus no mesmo ramo (Mizrahi, 2003:133).

Os novos imigrantes procedentes do Egito, Líbano e Síria, que chegaram ao país nos primeiros anos de 1950, eram comerciantes, industriais, financistas e profissionais ${ }^{4}$. Estes últimos constituiam a maioria dos judeus oriundos do Egito: engenheiros, farmacêuticos, diretores de bancos, contadores, professores, fotógrafos, vendedores, técnicos de tecelagem, tabaco, chá e outras especialidades e se fixaram no centro de São Paulo. Nesta cidade, aqueles que puderam imigrar com recursos, dedicaram-se aos negócios de importação e às 
finanças. Poucos profissionais egípcios conseguiram revalidar os seus diplomas. Apesar disso, encontraram posições ocupacionais na indústria automobilística, eletromecânica e farmacêutica. Outros foram absorvidos por conglomerados financeiros e bancários, pois além do conhecimento técnico, dispunham do domínio de línguas (Mizrahi, 2003: 197-198). Grande parte desses novos imigrantes se fixaram em Higienópolis, indo ao encontro dos judeus síriolibaneses das primeiras levas.

\section{A seleção dos entrevistados}

$\mathrm{O}$ estudo de homens tanto quanto o estudo de mulheres pode acarretar uma visão homogênea do sexo masculino e do sexo feminino, como se todos os homens fossem dominantes e membros de uma elite patriarcal, e que todas as mulheres fossem submissas e tivessem que lutar pela sua liberação.

Por mais que se seja um homem, um dominante, cada homem é por sua vez submetido às hierarquias masculinas. Todos os homens não têm o mesmo poder ou os mesmos privilégios. Alguns, que qualifico de grandes-homens ${ }^{5}$, têm privilégios que se exercem em detrimento das mulheres (como todos os homens), mas também em detrimento dos homens. A análise transversal das relações sociais de sexo abre outras pistas de análise e de reflexão que me parecem importante explorar nos próximos anos (...). Em suma, no momento em que o feminismo, por um lado, e o movimento gay, por outro, abalaram as bases naturalistas da dominação masculina, um imenso campo de pesquisa abre-se para todos e para todas. (Welzer-Lang, 2004: 123).

É dentro dessa perspectiva que trabalharemos com as relações de gênero, os valores e as atitudes religiosas de homens judeus, imigrantes e seus descendentes residentes na cidade de São Paulo.

Para este trabalho, entrevistamos sete homens e oito mulheres de três faixas etárias diferentes - dois homens e duas mulheres de até 35 anos de idade, referidos como primeiro grupo etário; um homem e quatro mulheres de 36 a 55 anos, segundo grupo etário; quatro homens e duas mulheres com mais de 56 anos de idade, terceiro grupo etário - ocupando uma parcela dos entrevistados posições de elite ${ }^{6}$. 0 sentido do termo elite foi utilizado de modo a compreender pessoas que ocupam posições de liderança e de respeito intelectual dentro da comunidade étnica, não necessariamente coincidindo com a condição financeira. Procuramos incluir entre os entrevistados os diferentes subgrupos étnicos e setores religiosos dentro do judaísmo. No acesso aos entrevistados utilizamos a técnica de bola de neve, partindo de diferentes 
contatos: conhecidos, parentes, amigos, vizinhança. Todas as entrevistas foram realizadas nas respectivas moradias dos entrevistados, exceção de duas em que os entrevistados vieram na minha própria casa. Os entrevistados serão referidos pelos seus pseudônimos para manter a sua privacidade, seguidos da sua idade e da sua ocupação profissional.

As informações foram agrupadas e analisadas a partir dos seguintes temas: a origem das familias; casamentos e arranjos familiares; os valores e as atitudes religiosas. Trabalharemos com a perspectiva dos homens na sua relação com as mulheres no espaço urbano.

\section{Algumas considerações sobre o processo migratório das famílias dos entrevistados}

No caso dos imigrantes judeus e dos seus descendentes, a questão do local de nascimento dos entrevistados e da proveniência de suas famílias é importante dada a diversidade de origem, que acarreta diferenciações internas ao grupo, como veremos ao longo desse trabalho. O movimento migratório dos pais dos entrevistados foi bastante amplo como se depreende pelo local de nascimento. Assinalamos o fluxo da Europa Oriental diretamente para o Brasil, para a Bolívia e posteriormente para o Brasil; a migração do Equador para os Estados Unidos e depois para São Paulo; e da Itália, Alemanha, Áustria, Tchecoslovaquia (República Tcheca), e Israel para o Brasil. Observamos um movimento internacional, provavelmente, ligado à oportunidade de obtenção de visto, muito dificil para qualquer judeu no período anterior à II Guerra Mundial.

O movimento migratório dos avós dos entrevistados, além daqueles procedentes da Europa Oriental, da Itália, Alemanha, Áustria, Tchecoslovaquia (República Tcheca), inclui também os que vieram do Líbano e da Síria diretamente para São Paulo e para o Nordeste do Brasil, migrando em seguida desta região para o Rio de Janeiro e depois para São Paulo.

Entre os entrevistados do segundo e terceiro grupo etário, incluindo seus pais e avós, observamos alguns casos de migração interna no estado de São Paulo em direção à capital e, do Rio de Janeiro, Salvador e Belo Horizonte em direção também à cidade de São Paulo. Apenas na primeira e terceira faixas etárias, é que encontramos imigrantes. Na terceira faixa, conforme já assinalamos, encontramos um entrevistado proveniente do Egito.

Esses movimentos migratórios abrangendo três gerações e em alguns casos, até mesmo quatro gerações levam a um afastamento dos laços familiares, como se depreende da fala de Alberto, aluno de pós-graduação em Língua e Literatura Hebraica, entrevistado do segundo grupo etário:

(...) A segunda mulher do meu avô teve uma menina, a Isabela, que nasceu no Brasil. Morou um tempo acho que em Israel, depois emigrou para os Estados Unidos. (...) Se eu 
cruzasse com ela na rua, com o filho dela, que hoje já deve ser adulto, eu não sei quem é. Não sei, não existe. É só uma linha numa biografia. (Alberto)

Nesse ponto há uma concordância com as mulheres entrevistadas, como uma jovem com menos de 35 anos, que trabalha em hotelaria, disse: "Acaba ficando um pouco sem família".

Esse processo migratório, dependendo da época histórica, tem a ver com o Holocausto conforme algumas referências dos entrevistados em relação aos seus pais e avós. Ou com a busca por melhores condições de vida, ou ainda em decorrência do anti-semitismo, entre as duas grandes guerras, ou do antisemitismo da década de 1950, no caso do Egito. Nem todos os avós imigrantes permaneceram no Brasil. Alguns migraram definitivamente para Israel.

Observamos o movimento migratório também entre os entrevistados e alguns dos seus filhos, sendo que nesse caso poderia estar ligado ao processo de globalização. Esses fluxos, na sua atualidade, estariam presentes também nos demais grupos étnicos que constituem a sociedade brasileira.

Comparando-se os três grupos etários, constatamos que os entrevistados dos dois grupos mais velhos demonstraram um conhecimento maior da experiência migratória do que a faixa mais nova, provavelmente, em razão da maioria ser filha de pais imigrantes, ou, como no caso de alguns do terceiro grupo, por eles próprios serem imigrantes. O Holocausto afetou os entrevistados, principalmente as famílias da segunda e terceira faixa etária, levando ao desaparecimento de grande parte de seus membros e, conseqüentemente, ao desconhecimento das gerações mais novas que dispõem apenas de retratos, e isso quando dispõem.

\section{Casamentos}

Em vários contos em iídiche, a língua falada pelos judeus da Europa Oriental, está presente o schadchen, o casamenteiro, ou a schadchente, a casamenteira, a pessoa que exercia o papel de intermediário entre os pais interessados em casar os(as) filhos(as). Na obra de Sholem Aleichem, "Teivie, o leiteiro", encontramos uma schadchente combinando o casamento do açougueiro da aldeia, um viúvo bem-de-vida, com Teivie, pai de 5 filhas e muito pobre. O que era visto como uma oportunidade para a filha escolhida, pois sem dote dificilmente uma moça casava ${ }^{7}$. De forma contraditória, as mulheres ocupavam um status inferior ao do homem, pois cabia aos homens conduzir as orações na sinagoga e estudar os livros sagrados. Contraditório porque às mulheres era concedida a possibilidade de trabalharem no mercado e manterem financeiramente as suas famílias, se casadas com estudiosos (Kosminsky, 2004).

À medida que a Haskalá, o iluminismo judaico, foi alcançando as várias localidades daquela região, as relações de gênero sofreram alterações, surgindo o casamento por escolha própria. No entanto, o costume deve ter se mantido e acompanhado os imigrantes rumo as Américas, pois encontramos referências 
relativamente recentes tanto em peças de teatro e filmes judaico-americanos - como por exemplo, a adaptação de "Teivie, o leiteiro" para a peça "Fiddler on the Roof" e o filme "Crossing Delancey" 8 - quanto em dados de pesquisas que temos coletado.

Todos deveriam casar-se. O casamento era um imperativo, tanto para o homem quanto para a mulher: casar-se e ter filhos, estava escrito no livro do Gênesis. Se das mulheres era exigido um dote, a qualidade valorizada nos homens era o conhecimento e a dedicação ao estudo dos livros sagrados. Ambos os lados também consideravam o Yikhes, isto é, a linhagem das famílias, o conhecimento dos livros sagrados no caso dos homens, e o desprezo a algumas profissões, consideradas inferiores, tais como, sapateiro etc. Os filhos não cogitavam em desobedecer aos pais, está determinado na Torá. Como ouvimos de um brasileiro judeu, filho de imigrantes da Europa Oriental, na cidade de São Paulo, há alguns anos, "os pais sabem melhor do que os filhos o que é bom para eles".

Os imigrantes procedentes da Europa Oriental, na cidade de São Paulo, conforme constatamos em pesquisa anterior (Kosminsky, 2000), à medida que os(as) filhos(as) iam crescendo, costumavam acompanhá-los(as) em festas realizadas na comunidade judaica, para que pudessem conhecer outros jovens e dai acontecer um namoro, seguido de casamento. Naquela pesquisa, não encontramos referências a casamentos arranjados, nem no que diz respeito aos entrevistados, filhos de imigrantes, nem quanto aos seus pais e mães. Alguns imigrantes casaram no Brasil, outros mandaram buscar as noivas que tinham ficado aguardando a chamada.

Entre os imigrantes judeus de língua árabe, procedentes da Síria e do Líbano, nas primeiras décadas do século $X X$, observamos que os casamentos eram arranjados entre famílias das comunidades de São Paulo e do Rio de Janeiro. Outras vezes, a noiva era mandada buscar naqueles países para casar em São Paulo ou no Rio. Grande parte dos imigrantes também casou os filhos com casamentos arranjados entre os próprios pais, procedentes das mesmas localidades. Esse padrão de casamento entre judeus de língua árabe também foi seguido, em vários casos, entre os netos dos imigrantes.

Entre os sujeitos da pesquisa dos três grupo etários, não encontramos referência a casamentos arranjados, mesmo entre os entrevistados mais velhos. Tudo indica que os casamentos tenham sido realizados por escolha própria dos interessados. Entre os entrevistados pertencentes ao primeiro grupo, em que a maioria é solteira, encontramos opiniões a respeito de casamentos religiosos e de casamentos com não-judeus.

Rafael, 28a (anos), comerciante, neto de imigrantes judeus sírio-libaneses, tanto do lado materno quanto do lado paterno, comenta os casamentos realizados na sua família:

(Os casamentos da família) Foram todos com mulheres judias. No do mais velho foi de uma maneira um pouco mais religiosa. O Moisés, ele não se casou, ele se juntou (com uma moça judia), mas parece que esse ano ele vai fazer a 
parte burocrática que seria o casamento (...). [risos] Ele já está morando com ela já faz uns 3 anos. E vivem juntos há 6 anos, mas morando junto há 3 anos. E eu estou namorando uma menina que também no caso é judia.

Para Alberto, 34a, estudante de pós-graduação, o único casado desta primeira faixa de corte, e que se considera "judeu ateu", o seu casamento com uma moça não-judia, não implicou em conversão: "Eu casei no ritual que é simplesmente o ritual, o ritual civil. (...) A gente fez pra facilitar a vida que já é complicada... [risos]"

Para as jovens menores de 35 anos, o ideal seria casar com um judeu "na medida do possível", caso contrário, casar com um não-judeu, afirma Luisa, 28a, médica. Nesta família há casamentos mistos. A segunda entrevistada, Ana, 30a, que trabalha com hotelaria - somente a mãe é judia, o pai é católico - concorda. Para as moças, o casamento com judeu não parece importante.

Comparando com a opinião dos dois homens, somente para um deles o casamento com mulher judia é imprescindível.

À medida que caminhamos em direção às faixas mais velhas, constatamos uma presença maior de casamentos endogâmicos, de acordo com o ritual religioso judaico. Este é o caso de Mauro, 36a, engenheiro, da segunda faixa etária:

O nosso casamento foi dentro do ritual [judaico], mas não foi um casamento totalmente ortodoxo. A gente fez uma cerimônia com um rabino ortodoxo, é feito aquele

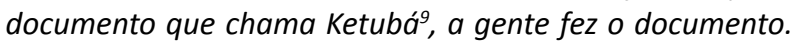
(...) Quer dizer, nosso casamento foi feito dentro desses preceitos. Agora, nossa festa, os muito religiosos judeus, eles separam homens e mulheres na festa. Nossa festa foi toda misturada, não teve essa separação. Foi uma festa... Graças a Deus eu gostei muito. Eu era muito jovem[risos].

Para as mulheres dessa faixa etária, Ivana, 37a, psicóloga, se casou com judeu segundo o ritual religioso; a outra, Denise, 42a, professora em escola judaica ortodoxa, casada, é ortodoxa. A terceira, Dora, 43a, professora em escola judaica, casou-se com um não-judeu, que está "voltando às raízes". De acordo com esta última, "Eu acho que a comunidade é preconceituosa com quem não casa. Eu acho. E eu senti isso na pele, por ter casado com 40 anos."

Dois pontos chamam a atenção nessa fala: primeiramente a questão da idade apropriada para o casamento no caso das mulheres e, em segundo lugar, a pressão que elas sofrem por parte da comunidade para que cumpram a determinação do Gênesis: "casai-vos e multiplicai-vos". O fato da entrevistada, Dora, 43a, professora, ter se casado aos 40 anos seria um indicativo do aumento da idade apropriada para o casamento, no que diz respeito às mulheres? Esse fato pode apontar para uma tendência, se considerarmos que na primeira 
faixa etária encontramos somente um entrevistado casado e as entrevistadas todas solteiras. E na segunda faixa, Ivana, 37a, psicóloga, casou-se aos 30 anos, enquanto que apenas a entrevistada ortodoxa, Denise, $42 \mathrm{a}$, professora, casou-se aos 20 anos.

A única solteira do segundo grupo etário, Marlene, 55a, tradutora juramentada do hebraico para o português não casou. Adotou um menino recém-nascido, que na época da entrevista contava com 12 anos de idade. Neste caso, encontramos um desafio ao preceito da obrigatoriedade do casamento e a adoção de uma criança não-judia, que está sendo criada como judia, o que não seria reconhecido pelos ortodoxos.

Essa segunda faixa, dos 36 aos 55 anos, em que encontramos uma solteira, Marlene, 55a, e outra que se casou "tarde", Dora, 43a, leva-nos a pensar na situação de desvantagem em que se encontram as mulheres mais velhas no Brasil, onde os homens preferem casar-se com mulheres jovens.

Entre os entrevistados da terceira faixa etária, ou seja, os mais velhos, encontramos tanto referências sucintas quanto longas explanações sobre os próprios casamentos. Inácio, 58a, representante comercial, informou que casou "dentro do religioso" e conta como conheceu a sua esposa:

A minha esposa eu conheci... eu fui pra Israel como voluntário na Guerra dos Seis Dias, em 1967. E ela já estava lá, que ela foi fazer um curso de professora de hebraico e nós nos encontramos através de uma amiga nossa. (...).

Naum, 60a, diretor de escola judaica e professor de curso preparatório para Bar-Mitzvá e Bat-Mitzvá ${ }^{10}$ e para noivos que pretendem casar-se dentro do ritual, disse que também se casou de acordo com os rituais judaicos. Descreve rapidamente como conheceu a sua esposa:

Amigos em comum nos apresentaram, fomos na Hebraica e fomos apresentados, começamos a sair e namorar.

Em relação ao casamento do filho, forneceu mais detalhes:

O meu filho se casou com a minha nora também na CIP (Congregação Israelita Paulista), então tiveram todos os rituais. Ele teve o Oifruf ${ }^{11}$, a chamada da Torá, um Shabat antes do casamento. Ela também foi na Mikve ${ }^{12}$ antes de se casar, teve aulas com a esposa de um rabino e fizemos o casamento na CIP, também comida kosher, os convidados amigos, judeus e não judeus, tradicionalmente trouxemos uma banda pra tocar na festa e exigimos que uma parte da festa fosse música judaica pra manter a tradição. 
José, 60a, engenheiro, lida com comércio exterior, mas há uns 7, 8 anos tem tido apenas trabalho esporádico. Segundo ele, "Houve uma época que quem mais trazia recursos para dentro de casa era eu, mas a partir de certo momento é minha mulher que traz mais recursos que eu."Ela é uma profissional da área de Educação. Eles vivem em união consensual há muitos anos: "Nenhum ritual. Nós nos gostamos e fomos morar juntos. [risos] Isso faz 32 anos". Ele lembra como conheceu a sua companheira, não-judia: "Conheci... conheci aqui em São Paulo, através de amigos".

David, 65a, comerciante, conta, entre risos, como conheceu a esposa. Ele veio do Egito, e em São Paulo vendia tecidos para as lojas. Ela, Askenazi, filha de imigrantes alemães, nascida em São Paulo: "Então assim que eu conheci a Dona Tamara, na loja do pai dela, na Lapa, já começamos e no fim deu no casamento". Embora o casal não tenha se conhecido em um ambiente judaico, estritamente falando, o casamento foi realizado de acordo com os preceitos, incluindo a concessão do dote. Ambos continuam trabalhando no comércio.

Nessa última faixa etária, encontramos uma viúva, Dinorah, 70a, originária de Portugal, dona-de-casa. Ela fala da perda do seu marido: "É muito triste".

Comparando-se os relatos dos três grupos etários de entrevistados, constatamos que do grupo intermediário para o mais jovem há uma tendência para a realização de casamentos na idade de 30, 40 anos com exceção dos mais ortodoxos que se casam muito jovens. Encontramos também a existência de união consensual nas duas últimas faixas de idade, o que de acordo com os dados estatísticos referentes ao país mostra o crescimento do número de uniões conjugais sem vínculos legais. ${ }^{13}$

Os entrevistados mais jovens, solteiros, consideram a possibilidade de casamento misto, com exceção dos mais religiosos, o que indicaria uma aproximação maior dos não-judeus. Quanto às relações de gênero tradicionais, não encontramos referências a casamentos arranjados, havendo, no entanto um caso de dote entre os mais velhos, indicando, em alguns casos, a possibilidade de permanência desse costume. A atuação da comunidade judaica em relação ao cumprimento do preceito do Gênesis ${ }^{14}$ parece permanecer principalmente entre os ortodoxos, cuja rede de contatos através de instituições, tais como o movimento Chabad, ultrapassa o país onde vivem.

\section{Arranjos familiares}

Considerando os arranjos familiares encontrados ao longo da pesquisa, nos surpreendemos diante da sua variedade e, especialmente, diante do aumento de casamentos não-endogâmicos e da permanência da afirmação da identidade judaica, contrariando este fato. 
Trataremos, de início, dos arranjos familiares, considerando os três grupos etários e os dados da pesquisa realizada por Elza Berquó (1998), baseada nos dados do censo. Levaremos em conta também as informações a respeito das famílias dos entrevistados.

Dos entrevistados do grupo mais jovem, em relação ao seu estado civil, somente um é casado, tem uma filha e a esposa não-judia está grávida de um menino. Todos os solteiros têm uma profissão, e todos eles moram com os pais. Essas famílias são constituídas por pai e mãe com dois ou três filhos. Observamos assim, famílias nucleares em que os filhos adultos, quer estejam ou não trabalhando, residem com os pais ${ }^{15}$. Em relação aos entrevistados do segundo grupo etário, todos são casados e somente uma é solteira. Todos trabalham. Essas famílias são constituídas de pai e mãe, com exceção de uma que é monoparental. Têm entre um e quatro filhos. A família monoparental é chefiada por uma mulher, que tem um filho adotivo. A família que tem quatro filhos é ortodoxa.

Entre os entrevistados casados, todos realizaram casamentos endogâmicos. Apenas uma mulher casou-se com um homem que tem uma origem judaica remota. Comparando-se os dois grupos etários, podemos observar que há uma tendência ao aumento do número de casamentos com não-judeus à medida que passamos do grupo intermediário para o primeiro, o que parece estar de acordo com a bibliografia consultada (Decol, 2000; Sorj, 1997).

Em relação aos entrevistados do terceiro grupo etário, quanto à união conjugal, encontramos uma maioria de casamentos endogâmicos, e um caso de uma união mista, consensual de 32 anos de existência, sendo o entrevistado judeu e a sua companheira não-judia. Na época em que se conheceram ela era viúva, com duas filhas pequenas.

Os entrevistados têm dois filhos cada. José, 60a, que não tem filhos próprios, considera os da sua mulher como próprios: "Mesmo, naturais, nenhum. Não tenho filhos. Sou casado, tenho duas meninas que são filhas do primeiro casamento da minha mulher que é viúva. A menor tinha 5 anos, a maior tinha 7 anos. Eram pequenas. Hoje uma tem 39 anos e a outra tem 37 anos."

Em se tratando de uma pesquisa qualitativa, o fato de que em cada arranjo familiar tenhamos encontrado dois filhos deve ser apreciado como um indicativo da menor presença de judeus ortodoxos nesta faixa etária e também como uma possibilidade de regulação da fecundidade, uma tendência que estamos observando no país e no mundo ocidental. Não quer dizer que todos os judeus dessa faixa etária tenham dois filhos e sim, que poderemos encontrar um grande número de pessoas, judeus desse grupo etário, nessa situação.

Alguns filhos desses entrevistados encontram-se casados, outros divorciados, ainda outros permanecem solteiros. A distribuição dos solteiros por local de moradia é a seguinte: em outro estado, com parente; em Israel; sozinho na 
mesma cidade dos pais (São Paulo); na casa dos pais. Entre aqueles que casaram ou que já foram casados, o número de filhos se situa entre um e dois filhos (netos dos entrevistados). O local de moradia dos casados compreende: Brasil (São Paulo), e Estados Unidos.

O terceiro grupo etário da pesquisa mostra similaridades com os dois grupos anteriores, ou seja, a tendência à diminuição do número de filhos. Possivelmente de forma diferente das faixas anteriores, notamos uma maior presença de muIheres que não se casaram, o que será discutido no item sobre valores, possibilitando assim uma maior compreensão das relações de gênero entre os imigrantes judeus e os seus descendentes.

\section{Os valores dos entrevistados}

Considerando a variedade interna ao grupo étnico judaico determinada pela procedência; pelos costumes e peculiaridades religiosas, questionamos como os imigrantes judeus e seus descendentes expressam as suas opiniões em relação aos valores indicativos das sociedades ocidentais urbanas modernas. Entre esses valores nos remeteremos àqueles que orientam as normas de relacionamento entre os sexos, tais como: virgindade, maternidade, orientação sexual, educação e trabalho da mulher; os relacionados às expectativas em relação ao sexo ao nascer; e finalmente, a opinião dos entrevistados em relação ao casamento endogâmico e à atuação da comunidade.

Ao discutirmos essas questões, precisamos levar em conta a sociedade brasileira, focalizando a cidade de São Paulo e também as sociedades de origem das famílias de imigrantes judeus e seus descendentes.

\section{Virgindade}

Os entrevistados mais jovens, todos solteiros, agrupados na primeira faixa etária, demonstraram aceitar relações sexuais anteriores ao casamento. A posição das mulheres é categórica, como disse Luisa, 28a: "Eu acho bobagem". Enquanto que a opinião do Rafael, 28 a, é contraditória, como se depreende das suas palavras. Ele discute a questão da virgindade de modo embaraçado entre risos e, ao mesmo tempo, mostra uma resignação diante dos "novos tempos" de liberdade sexual. Rafael, cujos avós maternos e paternos vieram do Líbano, assume uma posição que certamente seria o contrário da dos seus pais e avós:

A virgindade hoje em dia não é mais tabu. Hoje você não procura também... É difícil você achar uma menina virgem ou um homem, principalmente um homem. Mas, hoje as meninas que você encontrava antigamente, com mais facilidade, virgem está mais difícil porque todo mundo hoje está muito aberto. (...) Mas gostaria de casar com uma 
mulher virgem, mas não achei ainda. [risos] (...) Eu acho que seria legal. Mas não estou atrás de uma mulher que seja virgem. Eu acho que para mim seria legal. Todas que se apresentaram nenhuma era [risos] (Rafael, 28a).

Entre os entrevistados do segundo grupo etário, as respostas a respeito da virgindade não são semelhantes pelo fato de nesta faixa estar presente um homem e uma mulher ortodoxos. Diz Mauro, 36a:

Ih!!! [ênfase] Eu sou muito quadrado com relação a isso. [risos] Olha, a princípio, eu não sou a favor do sexo antes do casamento. A princípio eu não sou a favor, eu acho que o sexo tem que ser feito da maneira certa e com a pessoa certa. (...) Essa é a minha opinião. (Depois do casamento) Isso. Veja bem, casamento... Segundo a lei, o casamento não precisa de rabino, nem cerimônia, nada disso. Por que se institucionalizou o casamento? Porque senão vira uma bagunça total na sociedade. Então hoje tem um documento, tem testemunhas. (...) E para se consumar o casamento precisaria de sexo. (...) Então eu acho que a família é o pilar da sociedade.

De acordo com Denise, 42a, ortodoxa, "os dois lados casam virgens". Para as outras duas mulheres entrevistadas, Ivana, 37a e Dora, 43a, este assunto é ultrapassado.

Segundo as opiniões dos entrevistados do terceiro grupo etário, temos um reconhecimento objetivo da mudança de valores ocorrida em relação à virgindade na sociedade brasileira, A única exceção encontrada foi a da mulher viúva, de 70 anos, que considera "lindo casar virgem". Vejamos as opiniões masculinas. Inácio, 58a, afirma:

Eu acho que esse tabu já deixou de existir. Eu acho que a virgindade tanto da mulher como do homem é... essa questão de preservação, de pureza para o casamento. Eu acho que... bobagem.

Naum, 60a, considera que:

Houve uma época que este era o valor maior da mulher, $e$ isso definia se casava e com quem casava e quando casava ou se não casava. Eu acho que esse valor hoje, na sociedade moderna, está perdendo seu ímpeto. Na verdade, hoje, as pessoas que vão se casar, a maioria já mora junto, já vivem juntos e se casam depois de um tempo de viverem juntos. Então essa pergunta realmente não aparece, ela é mais freqüente nas familias ortodoxas. 
José, 60a, é mais pessoal na sua resposta, referindo-se a si próprio e às suas filhas:

Nunca foi uma preocupação minha já desde rapazinho, naquela época essa era uma questão importante na parte da sociedade. Nunca me preocupei com isso. Eu não acho que seja importante. Não foi para mim, não transmiti isso também para as nossas filhas. Elas também tiveram experiências sexuais antes do casamento, com o nosso conhecimento e aval e tudo.

David, 65a, confirma a opinião dos demais:

Bom. Na nossa época, eu não sei aqui no Brasil como que era, mas já na Europa e Israel já não se fazia questão de falar vou casar mais com uma que eu gosto dela, do que eu caso com uma virgem que eu não gosto. Mas, não fazia questão. Mas, com o tempo, aqui quando eu cheguei também estava um pouco assim... Passando.

As falas dos entrevistados mostram que todos eles, homens de idade diversas acompanharam as alterações dos padrões morais que preconizam a não manutenção da virgindade como pré-requisito para o casamento. As exceções encontradas correspondem aos ortodoxos. Os homens mais velhos, provavelmente pelo fato de terem sido afetados de modo diferente em relação à sexualidade pré-matrimonial, seguiram as modificações de comportamento.

\section{Maternidade/Paternidade}

A questão da maternidade provocou desde falas genéricas, pouco relacionadas à vida pessoal de cada um (a), até afirmações que poderiam ser consideradas "modernas", de acordo com as relações de gênero mais avançadas. Como um sinal de mudança das relações dentro da família brasileira (Berquó, 2002), embora não fizesse parte da nossa proposta de pesquisa, alguns entrevistados se manifestaram também a respeito da paternidade.

Rafael, 28a se preocupa com os custos da criação dos filhos:

Eu acho que... hoje em dia você ter um filho custa. Custa muito caro. Para você dar ao seu filho o que você teve ou às vezes até o que você não teve. Um ou dois filhos é o ponto máximo que hoje em dia você consegue ter. 
Entre as jovens solteiras, com menos de 35 anos, Ana, 30a concorda com o Rafael, "só vou ter filhos se tiver condições". Luisa, 28a assume uma postura crítica: "É uma opção de cada uma; não é porque alguém decidiu não ser mãe que ela é menos mulher por isso".

As mulheres de 36 a 55 anos de idade demonstram uma diversidade de opinião, embora todas tenham tido filhos. Ivana, 37a, casada e mãe de dois filhos, criticou o romantismo que envolve a maternidade. Marlene, 55a, solteira, é mãe adotiva de um menino, considera a maternidade importante: "É uma necessidade feminina". Dora, 43a, acha que ter filho requer uma família "estruturada". Denise, 42a, ortodoxa, mãe de quatro filhos, encara a maternidade como uma "produtividade feminina". A diversidade de opinião encontrada nas duas faixas etárias, em que duas mulheres criticam a visão antiquada da maternidade, provavelmente deve-se ao fato de se tratar de mulheres com uma visão de mundo mais atualizada, talvez mais ampla do que as demais.

Para David, 65a, pai de dois filhos, do terceiro grupo etário:

É... é opção de cada casal, quer dizer, se querem ter filhos tudo bem, se não querem... É opção de cada casal, não é uma regra pra todo mundo igual, não pode.

José, 60a, que vive em união consensual, há mais de 30 anos, afirma que apesar de não ter "filhos naturais", tem "duas meninas que são filhas do primeiro casamento da minha mulher, que é viúva. A menor tinha 5 anos, a maior tinha 7. Hoje uma tem 39 e a outra tem 37 anos". Para ele a maternidade/paternidade:

Acho ótimo, maravilhoso. [risos] Quer dizer, eu não tive a experiência de eu ir para a maternidade, a minha mulher ficar grávida, a gente acompanhar essa gravidez. Então isso eu fiz, essa parte que me faltou, eu completei com os netos, acompanhei tudo e tal. (...) Acho que fui pai. Fui pai e acho que... pelo menos procurei ser um bom pai.

Naum, 60a, casado, pai de um casal de filhos e avô de uma neta, da elite intelectual judaica, opina sobre a maternidade:

A vida deve continuar, eu acho que é importantíssimo, não só pelo preceito bíblico, mas simplesmente pela preservação da espécie e pela finalidade de nós deixarmos valores, $e$, alguém que nos segue depois que nós já não estivermos mais aqui, importantíssimo. E quanto aos filhos eu diria que... um pensamento moderno meu, não exatamente um pensamento judaico ortodoxo, dois ou três filhos estaria de bom tamanho. Não é tão fácil criar e a gente quer dar 
uma série de vantagens e valores pra eles. Ao contrário de famílias ortodoxas que, como não têm outro tipo de atividade a não ser dedicar-se o dia todo só a família, é que eles podem ter 6, 8, 10 filhos, uma família não ortodoxa já pensa um pouco diferente.

Inácio, 58a, casado, pai de dois filhos adultos solteiros que não residem mais com ele e a esposa, considera a maternidade importante:

Eu acho que sim (devem ter filhos). Porque a procriação faz parte do ser humano, como faz parte de todos os animais. Então a... a continuidade da espécie é necessário que haja procriação. É... eu acho que é muito mais saudável se isso é feito quando existe uma união, quando tem um casal que passa a viver junto que possa se dedicar à criação da criança, à educação e tudo mais...

A única mulher dessa última faixa etária, Dinorah, 70a, encara a maternidade com paixão e com um certo romantismo, semelhante à postura de algumas das mulheres de 36 a 55 anos de idade entrevistadas.

Constatamos em relação à maternidade: a predominância da maternidade tardia, entre os 30 e 40 anos, por parte dos entrevistados da primeira e da segunda faixa etária, sendo que nesta última encontramos uma mãe solteira e seu filho adotivo. Em contraposição a essa atitude, a posição romântica a respeito da maternidade é professada pela mulher mais velha e por aquela que adotou um menino. Encontramos os dois entrevistados ortodoxos, um homem com dois filhos e uma mulher com quatro filhos, exercendo a regulamentação da fecundidade, o que mostra um diferencial diante do grande número de ortodoxos que não procedem dessa forma. Notamos também uma participação maior do pai e uma relação mais igualitária entre homens e mulheres no que diz respeito à criação dos filhos. Essa alteração faria parte da "tendência à passagem de uma família hierárquica para uma família mais igualitária, tendência inicialmente mais visível nas camadas médias urbanas (Berquó, 1998: 415) " não constituindo, portanto, uma especificidade das famílias judias.

\section{Orientação sexual}

Um dos valores sugerido como indicativo de "modernidade" das relações sociais diz respeito à orientação sexual. No entanto, poucos foram os entrevistados que entenderam a questão. Somente depois do termo ter sido explicitado foi possível saber o que pensavam. As atitudes sobre homossexualidade podem ser descritas como de estranhamento, de indiferença e de consideração e amizade.

Rafael, 28a, se contradiz entre a indiferença e a discriminação: 
Não sou contra, cada um na sua. (...) Se a pessoa escolheu esse caminho, ela tem que freqüentar lugares que somente são para homossexuais ou se ela está no meio de outras pessoas que não são, ela tem que ser discreta. É o basicão sobre isso.

Entre as mulheres jovens, com menos de 35 anos, Ana, 30a afirma ter "muitos amigos homossexuais", e Luisa, 28a, se preocupa com o fato da homossexualidade levar à diminuição de parceiros heterossexuais. Nessa faixa etária, podemos afirmar que apenas o homem entrevistado demonstra preconceito em relação ao homossexualismo.

Mauro, 36a, ortodoxo "moderno", pertencente à segunda faixa etária, apega-se à psicologia e à Bíblia para resolver o problema da orientação sexual, no caso da homossexualidade:

Olha, com todo respeito ao homossexualismo, ao lesbianismo, ou qualquer outro tipo de sexo com animais, o incesto, eu não sou a favor, (...) a Bíblia chama de pecado. Eu sei que muitos deles têm problemas psicológicos. Na verdade, eu respeito. Eu respeito a escolha sexual de cada um, mas eu não sou a favor. Eu não acho que é certo. Eu sou a favor... Eu acredito em Deus e sou a favor da lei de Deus. Eu acho que Deus criou o côncavo e o convexo, e não para encaixar o côncavo como côncavo. Eu realmente acredito nisso.

Entre as mulheres do mesmo grupo etário de Mauro, com exceção de Denise, 42a, ortodoxa, o homossexualismo é visto como um direito. Denise, que se define como "rabínica", entende orientação sexual como educação sexual na escola e na família. Verificamos que o judaísmo ortodoxo, quer seja "moderno" ou não, não aceita o homossexualismo.

David, 65a, da terceira faixa etária, responde à questão sobre orientação sexual, entendendo-a como homossexualidade:

Chocado. Mas tanto que a gente começa a ler, e a ver, às vezes não é de... como que se fala? Sem-vergonhice, ou desvio da sociedade; às vezes que tem realmente problemas. Falei com psicólogas, falei com psiquiatras e eu vi que realmente, às vezes, o feto não se sabe se é menina ou menino. E quando já vai se formando, às vezes, as coisas mudam para lado ou para outro. Então já é um problema. Então não pode culpar, julgar, antes de saber as coisas como são.

Inácio, 58a, não considera a orientação sexual entendida como desejo afetivosexual dirigido à homossexualidade como 
[...]normal: Olha! O natural... A naturalidade do homem e da mulher. Homem nasceu, já que foram determinados dois sexos por Deus, que são formados dois sexos. Eu não sei definir se o homossexualismo é uma doença (...) Eu não acho normal uma atitude dessa. Eu não acho que seja natural uma coisa dessas mas, também não condeno.

José, 60 a, se define como uma pessoa sem preconceitos:

Não tenho nenhuma restrição. Convivi com homossexuais, conheci, conheço, não tenho nenhum preconceito, não tenho nada. (Em relação à homossexualidade feminina) Também não. Não tenho. Normal. Eu acho que é uma opção, e a gente tem que respeitar. A sociedade tem que respeitar.

Naum, 60a, explicita a sua opinião:

Eu não posso judaicamente dizer, 'a Torá proíbe' e ponto final. Ele existe, então eu tenho que encarar que o homossexual é um ser humano, criado pelo mesmo Deus. Eu acredito em Deus. É o mesmo Deus que me criou, então ele merece todo o meu respeito enquanto ser humano. A questão que se fala hoje em dia é sobre casamento entre homossexuais, isto eu estou de acordo com o judaísmo. $O$ judaísmo é contra o casamento de homossexuais. Eu creio que uma criança adotada por um casal homossexual, e que ou não tem a figura do pai ou não tem a figura da mãe, mas tem duas figuras, é um pouco complicado.

Dinorah, 70a, a única mulher dessa faixa etária, apieda-se dos homossexuais por ter tido um amigo que sofria muito por ser homossexual.

As falas dos entrevistados mostram em primeiro lugar o desconhecimento do termo orientação sexual. Quando entendido como homossexualidade, encontramos uma diversidade de opiniões tais como a aceitação, a condenação e a discriminação, predominando, no entanto, a tolerância. Essas opiniões independem da idade do entrevistado estando relacionadas à sua formação intelectual e à sua abertura para o mundo, o que evidentemente não ocorre entre os ortodoxos, que vivem à parte.

\section{Educação e trabalho da mulher}

Possivelmente as opiniões a respeito da educação e do trabalho da mulher possam ser equiparadas àquelas relativas à virgindade. Para Luisa, 28a, uma das mulheres jovens, apesar do avanço da posição da mulher na atualidade, "sempre sobra para a mulher, não tem jeito." 
Rafael, 28a, comerciante, solteiro, assume uma posição que vai de encontro às aspirações das mulheres da sociedade ocidental:

Tem que estudar, se formar e trabalhar. Para mim, eu procuro. Sempre procurei uma mulher que trabalhasse ou que tenha trabalhado. Porque hoje em dia não dá para um só bancar, como era antes, a despesa da casa. Então eu acho que se a mulher fica dentro de casa sem fazer nada, ainda mais quando não tem filho, pensa besteira; vira uma mulher fútil, sem princípios, sem conversa, sem diálogo, $e$ acaba, às vezes, estragando o próprio casamento.

Mauro, 36a, ortodoxo, casado, pai de uma filha com outro filho a caminho, pertencente à segunda faixa etária, mostra a contradição entre a educação "à moda antiga" e as necessidades atuais que obrigam a mulher a trabalhar:

Eu sou... eu acho que sou pouco quadrado com relação à posição da mulher. Em termos modernos eu acho que a mulher não pode mais ficar em casa à toa, acho que isso já passou. Mas, eu acho que ainda sou um pouco quadrado no sentido de que o homem e a mulher são diferentes. Eu acho que existem diferenças físicas e biológicas. (...) Então eu acho que mulher tem que trabalhar e tem que estudar. Agora eu acho que a mulher tem que se dedicar aos filhos, porque o homem nunca, com raríssimas exceções, o homem nunca vai ser tão bom quanto a mulher. Mas, infelizmente, com a emancipação da mulher, o salário do homem já não sustenta mais a casa. Então os dois têm que trabalhar. Eu gostaria que minha mulher dedicasse bem mais aos nossos filhos do que ela dedica agora. Isso quer dizer, trabalhar menos e se possível ter uma função de meio horário, mesmo mal remunerado. Eu acho que é muito importante a mulher se dedicar à família, muito importante.

Entre as mulheres da mesma faixa do Mauro, Ivana, 37a, discute a dificuldade de conciliar o trabalho com a criação dos filhos. Para Dora, 43a, "é importante para a mulher ter uma profissão, mesmo que não trabalhe". Denise, 42a, ortodoxa, aponta para as alterações dos papéis de pai e de mãe na sociedade atual, realçando a importância da mãe para a preservação do judaísmo. Todas as mulheres de idade entre 36 e 55 anos trabalham. Novamente, o homem e a mulher ortodoxos apresentam opiniões semelhantes embora aceitem o fato de que as mulheres têm que trabalhar para também participarem financeiramente das despesas da família.

Discutindo a questão da mulher trabalhar fora, David, 65a, do terceiro grupo etário, respondeu: "Eu acho que hoje a situação obriga e ... é necessário que ela trabalhe, porque não tem uma diferença entre homem e mulher hoje. Um se apóia no outro hoje". 
Inácio, 58a, vai além da simples aceitação do trabalho da mulher:

Eu acho que deveria haver realmente uma igualdade maior de cargos e de salários. Então eu acho que deveria ter o mesmo nível salarial, mesmo nível de aceitação $e$ comportamento.

José, 60a, acha que é

fundamental a mulher estudar e trabalhar: Conhecer a vida e procurar saber. Foi assim que a gente criou as meninas (as enteadas). Estudaram, se formaram e foram para $o$ mercado de trabalho.

Naum, 60a, considerado um intelectual importante no mundo judaico da cidade de São Paulo em razão das suas atividades religiosas, é categórico na sua afirmação:

Com certeza absoluta, a mulher deve estudar tanto quanto o homem, deve também trabalhar dentro da área que escolher, dentro das suas possibilidades. Lógico que ressalvada as condições da maternidade que tem que cuidar, gravidez é um período complicado, porque filho, às vezes, têm necessidade de mãe. Então vamos achar um horário compativel. Mas sem dúvida nenhuma, no mundo moderno, mulher deve estudar completamente e trabalhar também.

Pelo visto a totalidade dos entrevistados reconhece que, "nos tempos modernos" a mulher deve estudar e trabalhar fora de casa. Mesmo Mauro, $36 a$, judeu ortodoxo, que se considera um pouco "quadrado", está de acordo. Afinal, constata ele, hoje em dia, é impossível sustentar a família somente com o salário do marido.

\section{Divisão das tarefas domésticas}

Se todos os entrevistados são favoráveis ao trabalho da mulher fora de casa no plano do discurso, como fica essa questão no plano da ação? Os maridos estariam compartilhando as tarefas domésticas ou as mulheres estariam enfrentando uma dupla jornada de trabalho? Vejamos o que acontece, segundo os relatos dos entrevistados a respeito da divisão das tarefas da casa e da sua administração.

Para as famílias de classe média, que contam com o trabalho de uma empregada doméstica, essa questão parece prejudicada na medida em que nem o homem e nem a mulher realizam as tarefas domésticas. No caso de Ana, 30a, é a empregada quem faz o serviço da casa. A mãe, que não trabalha fora de casa, 
faz as compras. As contas são pagas pela Internet. Se for preciso ir ao banco, é a filha (entrevistada) quem vai. Na casa de Luisa, 28a, que também conta com empregada doméstica, "não existem tarefas só de homem ou só de mulher. Existem coisas que as pessoas gostam mais de fazer. Meu pai gosta de fazer supermercado, claro que não é uma obrigação". Em relação à administração da casa, essa mesma entrevistada afirma que seus pais atuam "em conjunto".

$\mathrm{Na}$ casa de Rafael, 28a, sefardita de origem libanesa, solteiro, morando com os pais, a mãe não trabalha fora e, mesmo tendo empregada doméstica, realiza algumas das tarefas da casa:

Da casa, quem cuida totalmente da casa é minha mãe. Não tem nenhuma divisão de tarefas. A divisão de tarefas, às vezes, quando tem alguma festa e ela precisa de um apoio, de uma ajuda. Daí eu ajudo a buscar as coisas que ela quer ou ir a ao supermercado ou algo do gênero. Porque, senão, normalmente ela que faz toda essa parte, desde supermercado, fazer o próprio alimento, fazer a limpeza da casa junto com a empregada, é mais ela mesmo.

Como podemos explicar o caso dessa família, que apesar de contar com uma empregada doméstica, o fazer comida é uma atribuição da mulher? Rafael explica:

A comida, ela é tipicamente árabe. [risos] Mistura um pouco com a comida portuguesa, aqui do Brasil, brasileira quer dizer. E... vai indo, não tem muita diferença na comida. Temperos fortes, comidas maravilhosas, [risos] que a mãe faz. Somos Kosher ${ }^{16}$ dentro de casa.

Nesse caso pertencer à classe média não esclarece a questão. Seguir a tradição da cozinha árabe-kosher, para essas famílias, exige a atuação da mulher na cozinha mesmo quando ela dispõe de empregada.

Sobre a administração dos rendimentos da família, diz Rafael: "Ela também. [risos]. Ela também. Então eu e o Moisés (irmão) damos uma mão superficial para ela no que ela precisa. Mas ela é que, a grosso modo, mexe com as coisas."

No caso do Rafael, a mãe parece desempenhar uma posição central e autoritária dentro da família. Enquanto que nas outras famílias as tarefas administrativas parecem estar mais divididas entre os pais e os filhos adultos. Poderia essa diferença ser explicada a partir da origem do sub-grupo étnico? Essa é uma hipótese a ser considerada, muito embora entre os judeus libaneses e egípcios o pai represente a autoridade máxima dentro da família.

Passando para a segunda faixa etária vemos que, mesmo a necessidade de manutenção da família implicando no trabalho da mulher fora de casa, nem sempre leva à sua auto-determinação, no sentido da administração financeira da casa, como podemos observar da fala do Mauro, 36a, ortodoxo: 
Minha mulher trabalha muito mais do que eu. Ela tem um horário, menos flexível do que o meu. Ela trabalha mais e ela ganha mais do que eu. [risos] Então, eu hoje talvez tenha mais funções em casa do que ela. Mas isso a gente não tem uma divisão muito rígida não. Quem puder faz.

Quanto à administração dos rendimentos da família, diz Mauro: "Sou eu, nós dois participamos. Mas normalmente eu que cuido. Normalmente sou eu [quem cuida das contas]."

Vejamos se há divisão de tarefas nas famílias das mulheres dessa segunda faixa etária. Para a Ivana, 37a, que trabalha fora de casa, o marido sobressai em relação aos demais pelo fato de participar tanto da divisão de tarefas, quanto da administração dos rendimentos. Na família de Denise, 42a, ortodoxa, que também trabalha fora de casa, destaca-se a comparação com Israel, onde a família viveu muitos anos: "Aqui no Brasil, abrasileirou. Tem mão-deobra extra, ele (o marido) faz menos. Mas ainda colabora com as crianças". $\mathrm{Na}$ administração dos rendimentos da família, o homem parece "o mais apropriado" para lidar com os números.

Na casa da Dora, 43a, ela e o marido trabalham. Eles moram com o filhinho no apartamento da mãe dela, e é esta senhora quem administra a casa. Eles também têm empregada. Marlene, 55a, que mora com o filho, também trabalha e quem cuida da casa é a empregada.

Passando para a terceira faixa etária, assinalamos uma divisão mais tradicional, principalmente, quando a mulher por algum motivo não trabalha fora, como depreendemos da fala de Inácio, 58a:

De certa maneira existe porque... é... eu trabalho em vendas, então eu saio muito, eu visito muitos clientes, mas o meu escritório também é em casa. E Lilian, com a idade que ela já está, que nós temos, que é 58 anos, é muito difícil achar trabalho. Ela é professora e não deu continuidade, não conseguiu mais dar aula. Já tentou de tudo, hoje ela trabalha fazendo tricô e crochê pra vender, mas... de certa maneira ela cuida da casa, ela cozinha, e eu trabalho. Quando é necessário eu participo também. Só não participo da cozinha, que eu não sei cozinhar. Mas o resto, inclusive, por incrivel que pareça, o supermercado sou eu quem faço, não é ela.

Nesse caso a administração dos rendimentos da família cabe ao marido:

Sou eu que faço. Porque infelizmente ainda o... todo o ganho de rendimentos é meu, ela não tem, não tem rendimento. O rendimento que ela faz hoje, o trabalho manual que ela tem feito é muito pequeno, dá para alguma coisa. Mas a administração toda da parte financeira é minha. (Inácio, 58a) 
Situação semelhante foi encontrada na entrevista com Naum, 60a:

Então, minha esposa costuma dizer que atrás de todo homem de sucesso tem uma mulher cansada. Então, as contas, o que fazer com o dinheiro, o que economizar, aonde aplicar, o que comprar, o que fazer desde que seja uma aplicação, eu decido. Os pagamentos e toda a parte de administração de contas, o que precisa pagar, o que precisa comprar e tudo o mais, a esposa que faz.

Embora José tenha 60 anos de idade, a divisão de tarefas na sua casa se aproxima daquela encontrada entre os casais mais jovens:

Acho que a gente faz em conjunto isso. Houve uma época que quem mais trazia recursos para dentro de casa era eu. Mas, a partir de certo momento é minha mulher que traz mais recursos que eu. Eu acho que é uma administração compartida.

A esposa de José trabalha. É uma profissional da área de educação. Este parece ser o grande diferencial. No entanto, mesmo quando a mulher trabalha no comércio ao lado do marido, a divisão tradicional se mantém como se depreende da fala de David, 65a:

Bom, a parte de gastar é com ela. A parte de financiamento é comigo. Então... É equilibrado. Ela passa os cheques e depois passa o talão para mim, para eu marcar lá o que ela gastou. Para cuidar, para não estourar a conta.

Talvez, premidos pelas circunstâncias econômicas, alguns entrevistados reconheçam a necessidade do trabalho da mulher fora de casa, mesmo entre o(a) ortodoxo(a) entrevistado(a). Outros assumem uma posição mais igualitária apontando a necessidade de uma companheira que também tenha instrução e com quem possam compartilhar a vida. Como todos os entrevistados pertencem às classes médias, contando uns com mais recursos do que outros, o fato de contarem com uma pessoa contratada para exercer as atividades domésticas libera a mulher para o mercado de trabalho, com exceção das mulheres mais velhas das famílias sefarditas. Embora quase todas as entrevistadas estejam trabalhando, tanto as solteiras quanto as casadas, parece haver um consenso de que, apesar de relações mais igualitárias na família, ainda "sobra mais para a mulher." Para os entrevistados, que moraram em países com mais recursos e com mão-de-obra mais cara, as relações entre homem e mulher e entre ambos e os filhos pareceram mais igualitárias nesses países do que no Brasil no que concerne ao trabalho e à execução das atividades domésticas. 


\section{Expectativas em relação ao sexo do filho}

Dentro da tradição judaica, o nascimento de um filho do sexo masculino é muito importante; é a cerimônia da sua circuncisão, executada por um Mohel, ${ }^{17}$ que irá significar a aliança com Deus. Esse ritual está presente em todos os subgrupos étnicos judeus, sendo que entre os sefarditas de origem árabe, quando o primeiro filho do casal é homem, essa cerimônia ganha uma importância ainda maior, por se tratar de uma organização familiar mais centrada na autoridade paterna do que aquela constituída por judeus askenazi. Não podemos esquecer que, excetuando o judaísmo reformista ${ }^{18}$, é ao homem que cabe o exercício das preces e a sua condução dentro da sinagoga. Esse fato conduziu a uma certa contradição na Europa Oriental, conforme já assinalamos, em que a mulher poderia até mesmo manter a família, o que não alterava o seu status religioso. Todavia, o papel da mulher no exercício doméstico da religião é fundamental, na medida em que lhe cabe os cuidados dos alimentos, segundo o ritual Kasher, a preparação da casa para o Shabat e para os demais dias do calendário judaico, como o Pessach, com suas comidas próprias. Além disso, a transmissão da identidade étnica judaica, de acordo com a lei rabínica, se dá através da mãe: é judeu todo aquele filho de mãe judia.

Vejamos como os entrevistados lidam com essa questão, começando com Mauro, 36a, ortodoxo:

Quando nasce menino tem o Brit Milá, a circuncisão. Quando nasce menina, a gente faz uma cerimônia de daro nome, que é feita na sinagoga com o Rabino. É um costume também dentro das possibilidades de cada um da gente fazer o Kidush ${ }^{19}$, que é oferecer alguma refeição para os nossos convidados. É um costume. Se nascer menino, vamos tentar fazer no oitavo dia, se o neném puder, a cerimônia de circuncisão com uma pessoa especializada. Dentro das nossas possibilidades. Se a gente puder pagar a gente faz num buffet. Se não puder, a gente faz no salão de festas do prédio mesmo. (E sobre a questão do sexo ao nascer?) Olha! Pra gente não faz a menor diferença, nós ficamos felizes com qualquer um dos dois.

Provavelmente a opinião de Mauro diz respeito ao fato dele ser ortodoxo moderno. Os ortodoxos tradicionais, tais como os que pertencem ao Chabad, demonstram uma clara preferência pelo nascimento dos filhos homens e não são favoráveis à regulamentação da fecundidade.

Entre as mulheres dessa segunda faixa etária, encontramos o seguinte: Ivana, 37a é judia secular, mas segue algumas das tradições. Fez o Brit Milá nos 
dois filhos. Um ponto ela tem em comum com Mauro, 36a: ambos não aceitam a oportunidade dada pela tecnologia que permite conhecer o sexo da criança antes do seu nascimento. Na cerimonia de circuncisão, Ivana deu os nomes dos avós em hebraico. Essa flexibilidade de escolher um nome para a criança na língua do país, um nome que esteja na moda, é usual entre os askenazi que dão o nome dos avós falecidos em iídiche ou hebraico na cerimônia religiosa. Entre os sefarditas, os filhos recebem o nome dos avós vivos, não levando em conta que o nome tenha caído em desuso.

A questão do nome como uma homengem ao parente próximo falecido é muito importante, mesmo que o filho seja adotado, como se depreende da fala de Marlene, 55a: "Ele recebeu o nome do meu irmão. Mas eu tinha uma... uma opção feminina para o nome. Também (em homenagem ao meu irmão). Ah, eu tinha uma opção masculina e feminina."

Denise, 42a, se declara ortodoxa rabínica, mãe de dois meninos e de duas meninas, explicita o significado do Brit Milá:

E circuncidamos os meninos. Brit Milá é Aliança que dá o vinculo com Deus! As meninas, a gente anuncia na sinagoga que nasceram e tem gente que faz uma festa quando a men ina nasce, ou tem quem ofereça um Kidush no Beit Haknésset ${ }^{20}$.

Notamos uma grande semelhança na atitude religiosa a respeito da circuncisão dos filhos e da importância do nome dado à criança, tanto entre os ortodoxos quanto entre aqueles que se declaram judeus seculares. Não constatamos diferenças entre homens e mulheres. Contudo fica evidente que o nascimento de um menino é muito mais importante do que de uma menina por toda a simbologia que envolve a circuncisão.

A conversa com David, 65a, sobre a expectativa do sexo do filho ao nascer foi marcada pela sua história de vida, um imigrante procedente do Egito:

Eu, pessoalmente, te falo a verdade, eu queria filhos. Eu vou te explicar porquê. Eu tenho quatro irmãs. Como nós éramos imigrantes, elas não tinham contato com rapazes judeus. (No sentido de fazer uma boa escolha. Das quatro, duas casaram com judeus e se separaram, uma ficou solteira e somente uma vive bem com o marido, também judeu) E eu, para não ter filhas e sentir que elas vão sofrer 0 que minhas irmãs sofreram, então eu preferia ter homens. Esse é o motivo. Mas, eu não tenho nada contra mulher ou contra homem. 
Inácio, 58a, procura expressar o sentimento judaico em relação ao nascimento do filho homem:

Eu, na realidade, gostaria inicialmente de ter um filho para poder brincar, andar, jogar bola, que eram as atividades que eu tive quando menino. Então eu gostaria de ter. $E$ aconteceu que meu primeiro filho foi um homem. Mas, eu não vejo que haja necessidade mesmo que seja homem. (...) Agora voltando para o lado do judaísmo, então os judeus, eles sempre acham que eles precisam de um filho homem, para dar a continuidade da própria raça e continuidade do nome, que é muito importante para o judeu.

Naum, 60a, pertencente à elite intelectual judaica, aponta para a alteração da expectativa do filho homem:

Gozado. Eu sempre queria primeiro uma menina e todo mundo achava estranho. Porque as famílias judias sempre têm que ter o primeiro filho, tem que ser homem. No sefaradi então mais ainda. Mas eu sempre preferi uma menina, $e$ justamente veio um menino. Vindo com saúde não faz diferença. (E essa questão de sobrevivência do nome, o fato de ser homem?) Eu acho que hoje já tem muito pouco a ver. Eu acho que a mulher está chegando a um patamar de igualdade com os homens que em muitos casos ela é exatamente igual, e em muitos casos até superou o homem. Então essa questão de nome e sobrenome a manter, se a pessoa não é digna o nome não significa absolutamente nada. O nome não vai trazer nenhum valor.

Constatamos que o nascimento de um filho homem é muito importante para as famílias judias, principalmente para as famílias sefarditas e ortodoxas (neste último caso, vinculadas ao movimento Chabad e outros grupos semelhantes), nas quais a autoridade do chefe da família é incontestável. A cerimônia do Brit Milá é, talvez, a mais importante do judaísmo, pois proporciona a continuidade da aliança com Deus aos descendentes, sendo realizada até mesmo pelos judeus seculares. A escolha do nome do filho ou filha segue diferentes tradições, mas todas têm em comum a continuidade dos nomes dos avós e de parentes próximos. Entre os askenazi, recebem o nome daqueles já falecidos e entre os sefarditas recebem o nome dos vivos. Quando o nome não está na moda ou a criança é do sexo oposto ao do parente homenageado, faz-se uma adaptação do nome masculino para o feminino ou coloca-se o nome em hebraico, traduzindose para um nome em português que seja do agrado dos pais. Essa prática é mais comum entre os askenazi do que entre os sefarditas. O sexo dos entrevistados parece não afetar essa importante prática religiosa. 


\section{Opinião a respeito do casamento endogâmico e a atuação da co- munidade}

A manutenção do casamento endogâmico é um dos principais elementos para a preservação da identidade étnica judaica. Há, no entanto, uma grande diferença relativa ao fato de quem é judeu: se a esposa for judia, os filhos nascidos dessa união serão judeus, reconhecimento este atestado pelos rabinos. Se o marido for judeu e a esposa não for, os filhos deste casamento não serão considerados judeus. Neste último caso, se a esposa se converter ao judaísmo, os filhos poderão ser aceitos como judeus, pelos reformistas e conservativos. Entre os ortodoxos, a aceitação dos conversos - seja homem ou mulher - é mais difícil, mas não impossível.

Vejamos como os entrevistados entendem essa questão de acordo com a sua idade e sexo, começando por Rafael, 28a, de origem sefardita-libanesa, solteiro:

É um valor (casar dentro da comunidade) e um princípio
meu, antes da minha família. Porque para mim a cronologia
é a seguinte: primeiro vem a religião, depois vem minha
família, depois vem o resto. É a minha concepção. Como
eu fui criado assim, eu absorvi desse jeito e eu gosto desse
jeito. Então eu acho que você tem que procurar o que você
vai se sentir bem para o futuro que você almeja. O que você
almeja? Que o seu filho faça um Bar-Mitzvá, então não
tem como você chegar e casar com uma mulher que não
seja judia, principalmente quando é a mulher que define a
religião.

Rafael conheceu a namorada

[...] através de apresentação. Uma prima dela, que já é casada, tem filhos, freqüenta a mesma sinagoga que eu. E eu sou muito amigo do marido dessa prima dela (...). (Quando casar pretendo que os meus filhos se casem dentro da comunidade) Sim. Sim.

Rafael explica o controle do casamento endogâmico:

Antigamente era uma maneira mais rígida. Você não tinha muita opção. Era imposto. Os pais antigamente impunham aos filhos que era aquilo e eles não tinham por onde escapar. Muitos poucos, se você ver o passado, muitos poucos conseguiram se afastar e casar com pessoas que não eram da religião. Hoje o índice de casamento misto é muito grande, às vezes o tipo de educação que você tem 
dentro de casa. Mas tem pessoas que também elas.... para elas não tem grandes valores essa questão de casar com judeu ou com não-judeu. Às vezes você encontra pessoas melhores fora da religião. Eu sei por que eu sempre convivi com pessoas que não eram da religião. Todos os meus relacionamentos foram com pessoas que não eram da religião. Só que chegou num ponto para mim que eu achei que precisava parar, sossegar e traçar uma meta para mim. Então a meta é esta.

E, realmente, Rafael cumpriu a sua meta, casou-se com a sua namorada, também sefardita: "São duas pessoas que já têm uma meta a querer seguir. Estão se juntando para ver se conseguem conciliar essas metas juntos".

Entre as entrevistadas dessa faixa etária, Ana, 30a, cujo pai é católico e a mãe é judia secular, o casamento exogâmico não se constitui em um problema. Luisa, 28a, que namora um rapaz não-judeu, mostrou-se preocupada a respeito do futuro: "(O casamento endogâmico) É um valor para minha família, é importante. É um valor pra mim também." Mesmo essa última entrevistada, que não é religiosa, mostra o seu apego à tradição judaica.

Como era de se esperar, os judeus ortodoxos mostram-se preocupados com a assimilação que seria resultante dos casamentos exogâmicos e que implicaria na perda da cultura judaica. É o que se depreende da fala do Mauro, 36a, ortodoxo moderno, casado, uma filha:

Na minha família muito próxima não tem (casamentos mistos). Mas, na minha família... um pouquinho distante... acho que são primos de não sei que grau, tem, existe. A questão que... Eu penso o seguinte: acho que a gente tem que se casar com pessoas que têm valores próximos aos nossos. Eu acho que quando a gente casa com uma pessoa que tem valores muito diferentes isso causa conflito. Acho que o conflito é inevitável. Eu acho que isso (o casamento misto) descaracteriza um pouco a comunidade, e diminui o número de judeus, que já é muito pequeno no mundo. Então quase todos os judeus casam com não-judeus lá (em Belo Horizonte, cidade de origem). Praticamente todos. Isso quer dizer que em alguns anos não vai ter mais comunidade judaica. Então eu acho que a assimilação em grandes proporções tem um lado muito negativo que é a perda da identidade cultural. Então, eu sou a favor, mas não em grandes proporções. E eu acho também em termos pessoais, em resumo. Eu acho que a gente deve sempre se casar com quem tem os mesmos valores do que a gente, porque senão o casamento não vai prá frente. (Conheci a minha esposa) Numa festa. [risos] Simples assim. Aqui em São Paulo. Prefiro (que os meus filhos se 
casem dentro da comunidade), claro que eu prefiro, com certeza. Eu acho a cultura judaica muito bonita e eu quero dar continuidade. Eu acho que se eles não se casarem dentro da comunidade, a gente vai perder essa cultura, a gente vai perder isso que a gente estuda, que a gente pratica. Então eu acho muito importante que eles se casem dentro da comunidade judaica.

Ao discutir as possíveis complicações que podem gerar os casamentos mistos, Mauro faz um paralelo com a diversidade religiosa existente entre os judeus:

Dentro da nossa religião existem várias correntes de pensamento. Existem mais religiosos, um pouquinho menos, até os nada religiosos. Entre os mais religiosos e menos religiosos já existe conflito. Conflito de valores mesmo.

Em sua opinião, as medidas que são tomadas para se evitar o casamento exogâmico são mínimas:

[risos] É quase não, é insignificante o que se faz para evitar o casamento misto. Eu não sei como é nas outras religiões. Eu acredito que todas as religiões têm algum trabalho nesse sentido por menor que seja, de manutenção, de tradição.

Diferente dos tempos passados:

Eu acho que antigamente as comunidades todas eram mais fechadas. E preservavam mais a cultura. Eu acho que o que pode e deve ser feito pela comunidade judaica, e eu acredito que também pelas outras comunidades, mas o objetivo não é só evitar casamentos entre comunidades. Não. $O$ que eu acho que se deve fazer é ensinar cultura desde cedo. Eu acho que a religião é importante, porque é a religião que trouxe para a nossa sociedade os valores éticos e morais. Então eu acho que as nossas crianças têm que ser ensinadas desde cedo a ter ética, moral e se comportar bem, para que não sejam só bons cidadãos no futuro, mas também para que mantenham seus valores e casem entre si também.

Vejamos as opiniões das mulheres dessa faixa etária a respeito do tipo de casamento. Ivana, 37 a, mãe de dois filhos, não considera um problema o casamento exogâmico e o fato de ter-se casado com judeu foi uma "coincidência". Marlene, 55a, mãe solteira de um filho adotivo, aponta para a importância relativa do casamento endogâmico: 
Eu acho que é importante. Porque eu acho que é importante é... A não ser..., quer dizer, eu também acho que não é muito... Caso não seja endogâmico, eu acho que tem que ter uma orientação única dentro da casa, quer dizer, por causa dos filhos.

Dora, 43a, cujo marido tem uma remota origem judia, considera importante o casamento endogâmico:

Seria interessante (dentro da comunidade). Assim, você pode casar com alguém que não seja da comunidade, contanto que tenha respeito. Então eu acho que é meio complicado depois com os filhos.

Nessa faixa etária, assim como na primeira, predomina a preocupação com a manutenção do casamento endogâmico e com a criação dos filhos dentro do judaísmo - mesmo entre os não ortodoxos.

David, 65a, pai de dois filhos, discute a importância do casamento dentro da coletividade judaica:

Bom, a minha formação eu acho que sim. Então meus pais me deram uma formação de judeu. Então eu quero ser judeu. Quero que meus filhos casem com judeu, para não ter aquela diferença. Porque os filhos... Os netos vão sofrer, porque a mãe vai querer puxar para o lado dela, então... deixa confuso lá os filhos. Foi então o que aconteceu com o primo meu, que ele separou. Os filhos fizeram Bar Mitzvá, Brit. Eles vão na sinagoga e não se sentem bem. A mãe, ela fazia até Kosher, tudo e no fim separaram. Eu acho que, lógico, ela voltou para a religião dela, porque é normal isso.

Inácio, 58a, casado, pai de dois filhos, aponta para a necessidade da tradição com o intuito de preservar a identidade judaica:

Pela tradição judaica, olhando desse ponto de vista, eu acho que é muito mais natural que haja ainda o casamento entre os judeus. Para a perpetuação da própria raça e da tradição. Mas.... os meus filhos, eu gostaria que os dois casassem com judeus. Porém, se ocorrer que não casem, não vai ser por isso que eu vou repudiar e vou renegá-los. A complicação que provoca (o casamento misto) é quando um dos... o judeu ele quer seguir a sua própria tradição, sua própria religião e o outro não segue, é que começam a haver os conflitos familiares. 
Da entrevista de Inácio se depreende como o ambiente judaico familiar exerce uma grande importância na socialização da criança dentro da tradição e dos valores judaicos, daí a preservação do casamento endogâmico.

Naum, 60a, casado, pai de dois filhos e avô de uma neta, explicita o que representa o casamento endogâmico:

Sem dúvida nenhuma (o casamento dentro do grupo judaico é um valor para a minha família) Eu sempre digo, 'O judeu não é melhor que o não-judeu, e não é pior. Ele é apenas diferente, com características próprias.' Então melhor seria se judeus apenas se casassem entre si, se eu quiser manter os valores do judaísmo. E não faltam pessoas judias para casar. Nosso povo tem bastante variedade. Quando casa uma pessoa judia com uma não-judia, é muito complicado. Sem dúvida nenhuma, faço questão absoluta que eles (meus filhos) se casem (dentro da comunidade judaica). Meu filho casou dentro da comunidade judaica. Eu não posso mandar neles. A vida é deles. Eles vão fazer o que quiserem. A minha preferência é essa. Eles sabem da minha preferência, mas... cada um é dono do seu nariz. (Como se controlava a opção conjugal ao longo das gerações) Em muitas épocas foi muito mais fácil não haver a assimilação porque o judeu era perseguido, era discriminado, vivia em gueto. Então era o não-judeu que obrigava o judeu a viver no meio da sua própria comunidade. Então era muito difícil ele casar fora da comunidade. $O$ problema era violentíssimo da parte dos judeus e muito maior ainda na parte dos não-judeus. Então era mais fácil manter a comunidade porque havia esse tipo de perseguição.

Nessas últimas colocações de Naum vemos a importância da atuação da sociedade abrangente: quando se trata de uma sociedade estamental ou até mesmo de uma sociedade de classes em que há discriminação, o grupo minoritário tende a casar-se entre si. Quando, pelo contrário, trata-se de uma sociedade em que o preconceito aparece mais diluido, como a brasileira, há uma maior possibilidade de casamentos exogâmicos.

A família, como agente socializador da afirmação da identidade judaica, parece desempenhar um papel muito mais forte do que a escola judaica. Mesmo a escola não-judaica passando os rituais religiosos da maioria católica, não é suficiente para quebrar o aprendizado religioso realizado na família e nas demais agências socializadoras, tais como a sinagoga e as associações juvenis.

Além dessa observação da família como agente socializador encarregado da transmissão das tradições e dos valores judaicos, constatamos que a maioria dos entrevistados mantém um apego à herança judaica transmitida pelos pais e avós - esse o principal argumento utilizado pelos defensores do casamento 
endogâmico. Além dessa preocupação, encontramos o receio, o estranhamento em relação ao não judeu, através do argumento de que esses casamentos "não dão certo", seguido da ansiedade a respeito do rumo religioso que os filhos adotarão, mesmo em caso da mãe ser judia. Quando a mãe é convertida ao judaísmo, há o questionamento a respeito da sua conversão e casos foram contados de mulheres conversas que, diante da separação, retornam à sua religião original. Então perguntam os entrevistados: "E os filhos, ficarão de qual lado? Que religião seguirão?"

Para os entrevistados ortodoxos integrados em alguma comunidade ortodoxa, seja ela Chabad ou alguma outra semelhante, a ameaça do casamento misto é ainda mais séria. Para começar, para eles já se trata de "casamento misto", quando um dos cônjuges é judeu não-ortodoxo - não haveria a garantia do prosseguimento dos rituais religiosos e nem da manutenção de um lar Kasher - ou quando se trata de um casamento askenazi-sefardita, uma vez que caberá ao pai a transmissão dos costumes e dos rituais religiosos, implicando na adequação da esposa aos procedimentos do marido. Não é qualquer conversão que é aceita pelos ortodoxos, e sim aquelas realizadas por rabinos ortodoxos respeitados pela comunidade. Dessa forma, a atuação das comunidades ortodoxas e sua grande preocupação de caráter ritualístico ${ }^{21}$ para a preservação do casamento endogâmico é impressionante, apesar dos seus membros acharem que as instituições judaicas não atuam o suficiente para a preservação do casamento interno ao grupo.

Apesar do grande número de casamentos mistos, um indicador da integração do grupo judeu à sociedade brasileira, encontramos um número respeitável de entrevistados para os quais o casamento endogâmico representa um valor, corroborando assim para a persistência do grupo étnico judeu.

\section{Considerações finais}

A partir da análise das informações aqui reunidas, constatamos que a adaptação de imigrantes judeus e seus descendentes entrevistados, pertencentes à camada média e média-alta, na cidade de São Paulo, se manifesta através das semelhanças encontradas nos novos padrões de relacionamento entre os membros das famílias das camadas médias urbanas do país, no que diz respeito a um padrão de relacionamento mais igualitário entre maridos e esposas e entre pais e filhos (Berquó, 1998). Esses padrões se manifestam através da liberação sexual; de uma divisão maior das tarefas da casa entre homens e mulheres; da participação maior dos pais na criação dos filhos; no reconhecimento do direito da mulher à educação e do respeito ao seu trabalho. Em relação aos arranjos familiares, também encontramos semelhanças com a sociedade luso-brasileira, através da existência de uniões consensuais. Ainda de forma semelhante, os jovens desse grupo étnico, mesmo quando já estão trabalhando, persistem morando com as suas famílias. 
Em relação à idade média para o casamento, encontramos entre os jovens judeus uma tendência para o casamento a partir dos 30 anos de idade, tanto da parte do homem quanto da mulher, diferenciando, portanto, da idade média dos jovens luso-brasileiros, que se casam mais cedo (Berquó, 1998). A exceção fica por conta dos ortodoxos que são a favor do casamento em torno de 18 anos para as meninas e dos 20 e poucos anos para os meninos. Os ortodoxos ligados ao movimento Chabad e a outros semelhantes, incluindo os ortodoxos modernos, são favoráveis à manutenção da virgindade tanto feminina quanto masculina. Os primeiros também são, de modo geral, contrários à regulamentação da fecundidade, não sendo esse o caso dos nossos entrevistados ortodoxos.

Em relação à preservação da identidade étnica encontramos um contínuo refazer dessa identidade no sentido de afastamento por meio de casamentos mistos ou do desinteresse pela sua preservação mesmo quando os dois cônjuges são judeus - o que é um indicativo de aceitação do grupo minoritário. Ao mesmo tempo encontramos casos de incorporação ao grupo judaico através da conversão de mulheres na sua maioria ${ }^{22}$. Os rituais religiosos relacionados ao ciclo da vida persistem entre a maioria dos entrevistados, todavia nem sempre de forma completa. Enquanto o judaísmo liberal parece encontrar-se em crise, tem havido um recrudescimento do judaísmo ortodoxo pela criação de novas sinagogas, de casas de estudo e de escolas próprias.

O processo de adaptação dos diferentes grupos judeus à cidade de São Paulo tem levado à aproximação uns dos outros e à diluição das diferenças através de casamentos e de freqüência a sinagogas e centros de recreação em comum.

A vida na cidade de São Paulo dificulta os contatos familiares tanto dos membros do grupo étnico quanto dos demais moradores da cidade. As possibilidades de contato mais freqüentes se restringem àqueles que moram no mesmo bairro dos seus familiares. Mesmo assim, as relações familiares e de amizade - internas ao grupo ou entre os seus membros e os não-judeus parecem muito próximas. A organização familiar judaica parece relacionada ao padrão de organização familiar do país, onde as relações familiares são bastante coesas (Kuznesof, 1988/1989). Do mesmo modo que as barreiras étnicas são o suficientemente permeáveis para permitir a interação e a sociabilidade entre os subgrupos judeus e a sociedade mais ampla.

As relações de gênero parecem explicar as conseqüências da imigração do casal ortodoxo e dos seus filhos que moraram em Israel por muitos anos. Com a vinda para o Brasil houve uma reformulação da distribuição das tarefas e da administração da casa. No entanto, nos dois casos de ortodoxos encontrados, o fato da mulher trabalhar fora e de dispor dos serviços de uma empregada doméstica atenua as relações de dominação de gênero que parecem se destacar nas famílias ortodoxas. As relações de gênero entre os judeus não-ortodoxos 
parecem mais igualitárias assemelhando-se àquelas mantidas entre os nãojudeus - ambos os grupos pertencentes às camadas médias e médias-altas, habitantes dos meios urbanos.

Como vimos, os homens e o masculino judeus não constituem um grupo homogêneo. Eles diferem entre si pelo fato de uns deterem mais poder do que outros, como é o caso de Naum, 60a, que detém o conhecimento religioso judaico. Além disso, cabe aos homens a administração do dinheiro recebidos por eles e pelas esposas. Eles também diferem em relação às mulheres, pois apesar da tendência observada a um padrão de relacionamento mais igualitário entre maridos e esposas, ainda "sobra mais para a mulher", como diz Luisa, 28a. De forma semelhante, as mulheres judias e o feminino judeus não são homogêneos. Algumas mulheres apresentam uma postura mais aberta para o mundo, até mesmo desafiadora, enquanto que outras, apesar de exercerem atividades remuneradas, demonstram uma posição de submissão em relação ao marido. As diferenças entre homens e mulheres judeus podem ser explicadas a partir da sociedade brasileira e do seu pertencimento às camadas médias e médias altas, considerando que em todas as famílias dos entrevistados(as) encontramos a presença de uma empregada doméstica, liberando assim a mulher para o trabalho remunerado fora de casa e afetando a divisão das tarefas domésticas entre maridos e esposas. Ainda de forma semelhante à sociedade brasileira, os laços familiares são mais coesos se comparados com as relações familiares encontradas nas famílias do Primeiro Mundo. $O$ que diferencia as atitudes de homens e mulheres judeus brasileiros em relação aos não-judeus brasileiros? 0 fato de procurarem preservar a sua prática religiosa através da manutenção do casamento endogâmico, o que é difícil numa sociedade como a brasileira em que há uma maior aceitação dos judeus do que em outras sociedades.

\section{Notas}

1 - Agradeço as valiosas contribuições de Elza Berquó, Maria Filomena Gregori, Célia Sakuria e Oswaldo Truzzi, colegas da caminhada na pesquisa que originou este trabalho.

2 - Os judeus não constituem um grupo étnico homogêneo. Apresentam diferenciações baseadas em diferentes procedências, línguas, costumes diversos e variedade de ritos. Referimos-nos às diferenças existentes entre os judeus da Europa Oriental, os judeus de língua alemã, os judeus sefarditas e os judeus orientais. Os judeus procedentes da Europa Central e Oriental são chamados de ashkenazim, no plural; ashkenazi, no singular), do original Ashkenaz, palavra hebraica que designa Alemanha, e refere-se ao judeu ou à tradição judaica dessa origem. O nome ashkenazi tem sido utilizado com esse significado desde o século XVI. Numa adaptação à grafia portuguesa, pode-se encontrar esses termos sem o " $\mathrm{h}$ ", ou também substituindo o " $\mathrm{k}$ " pelo "qu", tais como asquenazes ou asquenazim. Os sefarditas (em hebraico, 
sefardi no singular e sefardim no plural) compreendem os judeus procedentes da Península Ibérica e do Sul da Europa; os seus descendentes e os judeus do Oriente Médio. O nome hebraico Sefarad é de um reino na antiga Armênia, que os rabinos medievais identificaram como Espanha. A partir da palavra Sefarad, esses judeus são também designados sefaraditas. Os askenazim seguiam as práticas religiosas e as tradições dos rabinos e dos sábios da Palestina. Os sefarditas prosseguiram e elaboraram as práticas e tradições dos judeus na Babilônia. Os judeus askenazim distinguem-se dos judeus sefarditas pelo seu estilo de pensamento, a sua pronúncia do hebraico, aspectos da sua liturgia, costumes, hábitos alimentares e cerimoniais. Os askenazim falam iídiche, uma língua formada pelo alemão da Idade Média, com palavras eslavas e em hebraico, e escrita também em hebraico. A língua falada pelos sefarditas é o ladino, um dialeto espanhol. O ladino, inicialmente, baseou-se nos dialetos hispânicos dos séculos XIV e XV e, até o início do século XX, foi escrito em hebraico e seus caracteres se diferenciam da forma quadrada própria da escrita hebraica. Trata-se de uma escrita cursiva usada pelos judeus espanhóis na Idade Média. Os judeus sefarditas escreveram na sua maioria em árabe, mesmo quando escreviam sobre a Torá e o Talmud. Quando os judeus sefarditas foram expulsos de Portugal e da Espanha, eles se estabeleceram ao longo da costa do Mediterrâneo, na Holanda e na Inglaterra e nas suas colônias. Atualmente, o termo sefardita designa qualquer judeu que siga os rituais sefarditas, quer seja de ascendência espanhola ou não. Apesar de uma grande parte destes não ser de origem ibérica, e sim asiática e oriental. Na sua mais ampla acepção, sefardita é todo aquele que não é askenazi (Sayeg, 1977: 18). A questão da localização geográfica é de certo modo ultrapassada pela ideia de cultura, significando principalmente padrões de rituais religiosos e de alimentação. Judeus do Oriente Médio, do Norte da África e os judeus orientais encontram-se entre os sefarditas (Rosten, 1972: 643-645; 682-683). Os judeus-alemães podem ser considerados um grupo à parte, originalmente askenazim, que a partir do final do século XVIII foram atraídos pelo lluminismo, desenvolvendo a Haskalá ou o Iluminismo Judaico, abandonando o í́diche e adotando o alemão. (Kosminsky, 1985: 20-21). Os judeus orientais se dispersaram a partir da Palestina em direção ao Leste, até o Iraque, Iran, Afeganistão; em direção Sul, até a Península Arábica; e em direção Sudoeste ao Egito e, a partir dali para os demais países do Norte da África. Esses judeus nunca viveram na Europa, pois se transladaram da Palestina para outros países asiáticos e africanos. Falam a mesma língua dos países onde viveram. (Sayeg, 1977: 16).

3 - Com exceção da religião, afirma Rachel Mizrahi que, "os judeus da Moóca aproximaram-se dos 'sírio-libaneses', cristãos e muçulmanos e com eles mantinham negócios. O idioma comum, a estrutura patriarcal de suas famílias, a comida, a música e a dança foram fatores de identificação, gerados na milenar convivência, em terras árabes do Oriente Médio" (Mizrahi, 2003: 133).

4 - Os judeus-orientais procediam "de sinagogas conservadoras do Oriente-Médio" (Mizrahi, 2003: 90), e hoje, "a maioria dos freqüentadores das sinagogas é de origem egípcia", tendo aderido ao Beit Chabad, movimento religioso hassídico (Mizrahi, 2003: 191). Essas lideranças conservadoras, em termos religiosos e políticos, têm desempenhado um papel cada vez mais proeminente em relação às lideranças dos judeus-alemães liberais e conservativos e dos judeus da Europa Oriental nas instituições da coletividade. Paralelamente a isso, tem crescido a ortodoxia entre os judeus de ascendência europeia-oriental (Topel, 2005). Um sinal do crescimento da ortodoxia no mundo? 
5 - Welzer-Lang identifica "entre os grandes-homens aqueles que têm um poder político, religioso (ou mágico), econômico, bélico, administrativo, científico, universitário etc, (...) esse poder, instituído e instituidor, com os privilégios que os homens obtêm de suas funções nas relações com as mulheres e os homens." (Welzer-Lang, 2004: 123)

6 - O número de entrevistados diz respeito à procura da diversidade e não da uniformidade como repetição, uma vez que estamos trabalhando dentro da proposta de Burawoy do método do estudo de caso ampliado (Burawoy, 1991).

7 - Como um sinal de mudança das tradições, a moça convence o pai a recusar a oferta e a aprovar o seu casamento com aquele a quem ama.

8 - Crossing Delancey é uma comédia romântica, lançada em 1988, dirigida por Joan Micklin Silver, baseada na peça de Susan Sandler, que também escreveu o roteiro. É estrelado por Amy Irving e Peter Riegert. Mais detalhes, confira: http://en.wikipedia.org/wiki/Crossing_Delancey

9 - Ketubá, contrato de casamento.

10 - Bar-Mitzvá compreende o ritual através do qual o menino judeu de 13 anos de idade é admitido como membro adulto da comunidade judaica. Bat-Mitzvá, ritual semelhante, desempenhado pelas meninas judias aos 12 anos de idade.

11 - Em iídiche, Oifruf, o noivo é chamado para a leitura da Torá alguns dias antes do casamento.

12 - Mikve, do hebraico: "casa de banhos rituais utilizada, principalmente, para a purificação da mulher após o período menstrual, com o objetivo de que a vida marital seja recomeçada". (Topel, 2005: 297).

13 - Em relação aos dados censitários analisados por Elza Berquó (1998) referentes à idade média legal no ato do casamento no país, encontramos que "em 1994, os homens se casaram, em média, aos 27,6 anos, idade equivalente àquela registrada vinte anos antes. 0 mesmo sucedeu com as mulheres, cuja idade quando do casamento civil variou de 23,7 a 24,1 anos entre 1974 e 1994." (Berquó, 1998: 416). Na nossa pesquisa, encontramos uma tendência para o casamento a partir dos 30 anos de idade, tanto da parte do homem quanto da mulher, o que pode ser um indicativo de alteração das relações entre os sexos, com exceção dos ortodoxos que persistem casando-se jovens, as mulheres em torno dos 18 anos e os homens por volta dos 20 anos. A autora aponta também para o crescimento do número de uniões conjugais sem vínculos legais e de arranjos monoparentais na família brasileira nas últimas décadas, dados esses que vão de encontro às informações desta pesquisa.

14 - "Crescei e multiplicai".

15 - Mostra Elza Berquó (1998) que, "Morar sozinho em um domicílio é uma situação que apresenta índices ascendentes no conjunto dos arranjos domésticos. De 5,8\% em 1970, o número dessa configuração cresceu para 6,5\% em 1980 e para 8,1\% em 1995." No entanto, esse crescimento "está longe de ter o peso relativo que tem em alguns países do chamado Primeiro Mundo, como a Grã-Bretanha, por exemplo, onde o percentual de sozinhos corresponde a $25 \%$ da população, mesmo levando-se em consideração os contextos culturais e políticos diferentes." (Berquó, 1998: 432-433). Destaca a autora que morar sozinho "tem significados distintos conforme a faixa etária em que se encontra o indivíduo. (...) Predominam, entre os 
sozinhos, as pessoas com sessenta anos ou mais, o que correspondeu a $43 \%$ em 1995, mulheres em sua maioria" (Berquó, 1998: 434). A Tabela 9, "Estrutura etária de homens e mulheres que moram sozinhos Brasil, 1980 e 1995," elaborada a partir dos dados da Fundação IBGE, censo de 1980 e PNAD de 1995, evidencia um decréscimo da percentagem de jovens, da faixa etária de 15 a 29 anos: em 1980, 25,1\% de homens e 9,4\% de mulheres moravam sozinhos, e o ano de 1995, registra 20,5\% de homens e 8,0\% de mulheres residindo nessa situação (Berquó, 1998: 434). Esses dados são corroborados por Carlos Welti para toda a América Latina: "A juventude latino-americana de hoje permanece mais tempo em casa com seus pais do que antes. Isso é devido ao aumento de anos empregados em estudar e à dificuldade em encontrar um trabalho pago que preencha as suas aspirações" (Welti, 2002: 283. Tradução nossa).

16 - Kosher em iídiche; Kasher em hebraico (adjetivo); Kashrut em hebraico (substantivo). Os procedimentos utilizados para manter a casa, cozer os alimentos segundo os rituais.

17 - Mohel, em hebraico, pessoa especialmente designada para essa finalidade dentro da comunidade.

18 - Judaísmo reformista, uma corrente do judaismo que surgiu na Alemanha e que foi bastante influenciada pelo protestantismo. Nesse grupo a mulher pode exercer o mesmo papel que o homem na sinagoga, inclusive ser ordenada rabina. Essa corrente está muito pouco representada no Brasil e na cidade de São Paulo, onde a presença maior é de judeus conservativos, tradicionais e ortodoxos. Enquanto que entre os conservativos, homens e mulheres podem sentar-se na sinagoga uns ao lado dos outros, entre os tradicionais e os ortodoxos, as mulheres são mantidas à parte, separadas por uma cortina ou colocadas no primeiro andar, se os homens estiverem rezando no térreo.

19 - Kidush, a benção do vinho oferecida por alguém na sinagoga.

20 - Beit Haknésset, em hebraico, a sinagoga.

21 - Afirma Marta Topel (2005), baseando-se em vários autores, que "o termo ortodoxia é inapropriado para designar os judeus observantes, já que o que distingue os judeus que ficaram conhecidos como ortodoxos não é a doxa (a crença), e sim um estilo de vida fixado no ritual". (p.50).

22 - Esses casos de conversão de mulheres não foram discutidos neste artigo.

\section{Referências bibliográficas}

ALEICHEM, Sholem. Tevye the Dairyman and the Railroad Stories. Nova York: Shochen Books, 1996.

BERQUÓ, Elza. Arranjos familiares no Brasil: Uma visão demográfica.. In: NOVAIS, Fernando; SCHWARCZ, Lilia M. (orgs). História da vida privada no Brasil. vol.4. São Paulo: Companhia das Letras, 1998. Pp. 411-437.

BURAWOY, Michael. Ethnography Unbound. Berkeley: University of California Press, 1991.

DECOL, René D. Judeus no Brasil: explorando os dados censitários. Revista Brasileira de 
Ciências Sociais, São Paulo, n. 46, 2000, 1 CD (Coleção da Revista Brasileira de Ciências Sociais, ANPOCS, 25 anos)

FAUSTO, Boris. Negócios e ócios: histórias da imigração. São Paulo: Companhia das Letras, 1997.

FEBROT, Luiz Israel. Cidades judaicas: Gênesis. In: MEDINA, Cremilda (org.). Paulicéia prometida. São Paulo: CJE/ECA/USP, 1990.

KOSMINSKY, Ethel. Questões de gênero em estudos comparatives de imigração: mulheres judias em São Paulo e em Nova York. Cadernos Pagu, n. 23, julho-dezembro, 2004. pp. 279-328.

. Os judeus no bairro do Bom Retiro (São Paulo: 1925-1955). Cadernos CERU, São Paulo, série2, n. 13, 2002, pp. 47-71.

. Memórias da infância: As filhas de imigrantes judeus no Brasil. In: Cadernos CERU, série 2, n. 11, 2000, pp. 47-63.

. Rolândia a Terra Prometida: Judeus refugiados do Nazismo no Norte do Paraná. São Paulo: FFLCH/Centro de Estudos Judaicos/USP, 1985.

Kuznesof, ElizabethA. A família na sociedade brasileira: parentesco, clientelismo e estrutura social (São Paulo, 1700-1980), Revista Brasileira de História, São Paulo, vol. 9, n. 17, set. 1988/fev. 1989, pp. 37-63.

LESSER, Jeffrey. O Brasil e a questão judaica: imigração, diplomacia e preconceito. Rio de Janeiro: Imago, 1995.

MIZRAHI, Rachel. Imigrantes judeus do Oriente Médio: São Paulo e Rio de Janeiro. São Paulo: Ateliê Editorial, 2003.

ROSTEN'S, Leo. Treasure of Jewish Quotation. Nova York: McGraw-Hill, 1972.

SAYEG, Hilda Saaban. La Discriminación contra los judios orientales en Israel. Madrid: Fundamentos, 1977.

SORJ, Bila. Conversões e casamentos "mistos": A produção de "novos judeus" no Brasil. In: SORJ, Bila (org.) Identidades judaicas no Brasil contemporâneo. Rio de Janeiro: Imago, 1997.

TOPEL, Marta. Jerusalém \& São Paulo: A nova ortodoxia judaica em cena. Rio de Janeiro: Topbooks; São Paulo: FAPESP; Associação Universitária de Cultura Judaica, 2005.

WELTI, Carlos. Adolescents in Latin América: facing the future with skepticism. In: BROWN, B. Bradford; LARSON, Reed W.; SARASWATHI, T.S. (orgs). The world's youth: adolescence in eight Regions of the Globe. Cambridge: Cambridge University, 2002. Pp. 276-306.

WELZER-LANG, Daniel. Os homens e o masculino numa perspectiva de relações sociais de sexo. In:SCHPUN, Mônica Raisa. (Org.). Masculinidades. São Paulo: Boitempo Editorial; Santa Cruz do Sul: Edunisc, 2004. Pp. 107-128. 


\title{
RESUMO
}

Neste trabalho, pretendemos discutir as relações de gênero, mostrando o lado daquele que é visto como "dominante", isto é, o ponto de vista masculino. Pretendemos mostrar que o masculino não é único. Os homens e o masculino não constituem um grupo homogêneo, como se depreende das relações dos homens entre si, e das relações entre os homens e as mulheres. O nosso objetivo é, dentro dessa perspectiva, discutir as relações de gênero de entrevistados judeus, imigrantes e seus descendentes, residentes na cidade de São Paulo. Com essa finalidade, utilizando a técnica da "bola de neve", coletamos entrevistas em profundidade com homens judeus de três faixas etárias, ocupando diferentes posições sociais e também de origens diversas no ano de 2004. A análise das entrevistas com mulheres judias será relacionada com as dos homens, buscando estabelecer comparações, diferenças e semelhanças. Muito embora esta seja uma pesquisa qualitativa, os seus resultados serão comparados com os resultados da análise demográfica referente a determinados padrões de comportamento encontrados no país.

Palavras-chave: imigrantes e descendentes judeus, relações de gênero, cidade de São Paulo.

\begin{abstract}
This article analyses the gender relationship of Jewish immigrant men and their descendants from the male perspective in São Paulo City. I demonstrate that men and male are not an homogenous group, although one could consider male as the dominant sex. Men have different social relationships among them, and between them and women. I collected deep interviews with Jewish men who belong to three age cohorts, different social positions, and different national origin. I gathered the interviews through the "snow-ball" technique in 2004. I compare the men's interviews to the women's ones in order to verify similarities and differences between the two goups. Although this is a qualitative research, its results are compared to Brazilian demographic behavior patterns.
\end{abstract}

Key-words: Jewish immigrants and descendants, gender relationships, São Paulo City. 